\title{
Influence of clear cell carcinoma on the post- hepatectomy prognosis of patients with hepatocellular carcinoma
}

\section{Yongheng Deng}

Guanxi Medical University Cancer Hospital

\section{Shaoliang Zhu}

Guangxi Medical University Cancer Hospital

\section{Lunan Qi}

Guangxi Medical University Cancer Hospital

\section{Zushun Chen ( $\nabla$ qiyk225@163.com )}

Guangxi Medical University Center Hospital

\section{Liang Ma}

Guangxi Medical University Cancer Hospital

\section{Research}

Keywords: clear cell carcinoma, hepatocellular carcinoma, hepatectomy, prognosis

Posted Date: April 2nd, 2021

DOl: https://doi.org/10.21203/rs.3.rs-368877/v1

License: (c) (1) This work is licensed under a Creative Commons Attribution 4.0 International License. Read Full License

Version of Record: A version of this preprint was published at Future Oncology on December 8th, 2021. See the published version at https://doi.org/10.2217/fon-2021-0381. 


\section{Abstract}

Background To evaluate whether the presence of clear cell carcinoma in patients with hepatocellular carcinoma affects their prognosis after hepatectomy.

Methods Data were retrospectively analyzed for 470 patients with hepatocellular carcinoma, of whom 239 also had clear cell carcinoma. All patients were treated by hepatectomy at our hospital between October 2007 and March 2020. Overall survival (OS) and disease-free survival (DFS) were compared between patients with or without clear cell carcinoma. A Cox proportional hazards model was used to identify factors independently associated with survival. A nomogram was formulated to predict long-term prognosis of patients with hepatocellular carcinoma containing clear cell carcinoma following hepatectomy.

Results The presence of clear cell carcinoma was associated with significantly higher DFS $(P=0.007)$ and OS $(P<0.001)$. Multivariate analysis identified the following factors as significantly associated with DFS: alpha-fetoprotein level (AFP), tumor size, liver cirrhosis, satellite nodules and portal vein tumor thrombosis (PVTT). The following factors were significantly associated with OS: tumor size, satellite nodules, capsule formation and $\mathrm{Ki}-67$. A nomogram incorporating these independent prognostic factors showed a concordance index of 0.660 for predicting DFS and an index of 0.730 for predicting OS.

Conclusion Clear cell carcinoma is associated with better post-resection prognosis of patients with hepatocellular carcinoma. Tumor size and satellite nodules may be independent predictors of OS and DFS.

\section{Introduction}

Primary hepatocellular carcinoma (HCC) is, worldwide, the fifth most common cancer and the second most common cause of death from cancer [1]. Primary clear cell carcinoma of the liver (PCCCL) is a histological subtype of HCC in which tumors contain at least $50 \%$ of cells whose cytoplasm does not stain with hematoxylin or eosin [2, 3]. PCCCL accounts for $0.4-37 \%$ of HCC cases [4, 5], but a substantial proportion of HCC patients may present sub-PCCCL extents of clear cell carcinoma. At our hospital, approximately $12 \%$ of HCC patients have PCCCL or some presence of clear cell carcinoma.

Compared to other subtypes of HCC, PCCCL is associated with higher rates of HCV infection, pseudocapsule formation and liver cirrhosis, but a lower rate of vascular invasion $[3,4,6,7]$. Numerous studies indicate that it is associated with better prognosis than other HCC subtypes [6, 8-11]. Factors that appear to independently influence prognosis of PCCCL patients are high a-fetoprotein (AFP) level, tumor size, liver cirrhosis, vascular invasion, and tumor encapsulation $[9,10,12,13]$. Few studies have examined the prognosis of HCC patients whose clear cell carcinoma falls short of PCCCL.

To address this question, we retrospectively compared survival and recurrence data for 239 patients with HCC containing clear cell carcinoma and 231 patients with HCC without clear cell carcinoma, all of whom 
underwent hepatectomy at our hospital. Our aim was to identify factors that independently influence recurrence and survival, and subsequently develop a nomogram to predict prognosis of HCC patients with clear cell carcinoma.

\section{Materials And Methods}

\section{Patients}

Data were retrospectively analyzed for 239 patients with HCC containing clear cell carcinoma (regardless of clear cell proportion) and 231 with HCC without clear cell carcinoma, all of whom underwent hepatectomy at our hospital between October 2007 and March 2020. Diagnosis of clear cell carcinoma was confirmed by at least two pathologists based on histopathology of surgical samples (Fig. 1).

\section{Hepatectomy}

For all patients in our study, liver resection was proposed because they were assigned to Child-Pugh class A or B, and scored < 8 points in the Model for End-stage Liver Disease. Preoperative ultrasonography and contrast computed tomography were routinely performed to determine tumor location and assess vascular anatomy of the liver. Hepatic resection was performed as described [14] with the aim of complete tumor removal as well as maximum preservation of remnant liver volume. In nearly all patients, intermittent Pringle's maneuvers were carried out, in which the portal triad was clamped for less than 20 min and then released at 5-min intervals; alternatively, hemivascular occlusion was applied [15]. Large vessels and bile ducts were ligated separately during liver dissection. Liver parenchyma was transected gradually from front to back and from shallow to deep, leading to tumor resection [10]. The resection margin was $1 \mathrm{~cm}$ beyond the tumor, and surgical margins were negative based on pathology.

\section{Follow-up and management}

In the first month after hepatectomy, AFP level was assayed in patients, and hepatic ultrasonography as well as dynamic liver computed tomography were performed. Every 2-3 months during the first postoperative year and at least every 3-4 months afterward, patients were followed-up regularly and monitored for recurrence based on AFP level and hepatic ultrasonography. Every 6 months, the abdomen and chest were scanned by computed tomography. Overall survival (OS) was defined as the interval from the date of hepatectomy to the date of death or of last follow-up. Disease-free survival (DFS) was defined as the interval from the date of hepatectomy until the diagnosis of tumor recurrence or last follow-up. When tumor recurrence was diagnosed, secondary hepatectomy, radiofrequency ablation or transcatheter arterial chemoembolization was carried out, depending on the patient's condition and wishes.

\section{Statistical analysis}

Continuous data were compared between patients with or without clear cell carcinoma using Student's $t$ test, while categorical variables were compared using the chi-squared or Fisher's exact tests. Cumulative survival times were calculated by the Kaplan-Meier method and compared between groups using the logrank test. Independent prognostic factors were identified first by conducting univariate analysis, and the variables showing a significant relationship were entered into a Cox proportional hazards model. All 
statistical analyses were performed using SPSS 23.0 (IBM, Armonk, NY, USA). Differences associated with $\mathrm{P}<0.05$ were considered statistically significant. A prognostic nomogram was developed using Empower Statas 2.0 (X\&Y Solutions, Boston, USA), which was also used to determine the concordance index (C-index) and calibration curve.

\section{Results}

\section{Clinicopathological characteristics}

The patients with or without clear cell carcinoma did not differ significantly in Edmondson grade, capsule formation, tumor number, Child-Pugh class, cirrhosis or infection with hepatitis B virus infection (Supplementary Table 1). Patients with clear cell carcinoma had significantly lower AFP levels, significantly lower Ki-67 levels, significantly smaller tumors and significantly lower incidences of portal vein tumor thrombosis (PVTT), satellite nodules, microvascular invasion (MVI) and perioperative blood transfusion. Patients with clear cell carcinoma were significantly older and more likely to be women than those without clear cell carcinoma.

\section{Postoperative follow-up}

Patients with clear cell carcinoma showed mean DFS of 33.6 months $(95 \%$ confidence interval [Cl] $28.8-$ 38.4) and median DFS of 16.6 months $(95 \% \mathrm{Cl} 10.2-23.0)$. They showed rates of $1-, 3-$, and 5 -year DFS of $56.60 \%, 34.50 \%$, and $30.30 \%$. These rates were significantly higher than the corresponding rates for patients without clear cell carcinoma $(45.7 \%, 25.7 \%, 18.8 \% ; P=0.007$, Fig. 2). Patients with clear cell carcinoma showed mean OS of 66.4 months $(95 \% \mathrm{Cl} 58.8-74.0)$ and median OS of 79.7 months $(95 \% \mathrm{Cl}$ 67.2-92.2). They showed rates of $1-, 3$-, and 5 -year OS of $86.4 \%, 66.5 \%$, and $57.9 \%$, which were significantly higher than the corresponding rates for patients without clear cell carcinoma $(68.7 \%, 46 \%$, $38.8 \% ; P<0.001$, Fig. 2).

\section{Predictors of DFS in HCC patients with clear cell carcinoma}

Univariate analysis showed that liver cirrhosis (Supplementary Fig. 1), tumor number, tumor size (Supplementary Fig. 1), satellite nodules (Supplementary Fig. 1), AFP (Supplementary Fig. 1), MVI, capsule formation, PVTT (Supplementary Fig. 1), Barcelona Clinic Liver Cancer (BCLC) stage and Ki-67 were significantly associated with DFS of patients with clear cell carcinoma. Cox regression identified five variables that independently predicted DFS (Table 1): liver cirrhosis (hazard ratio [HR] $2.023,95 \% \mathrm{Cl}$ 1.127-3.631, $P=0.018$ ), tumor size (HR 2.01, 95\% Cl 1.388-2.912, $P<0.001$ ), satellite nodules (HR 0.544, $95 \% \mathrm{Cl} 0.343-0.863, P=0.01)$, AFP (HR 1.512, 95\% Cl 1.057-2.161, $P=0.023)$ and PVTT (HR $0.531,95 \% \mathrm{Cl}$ $0.312-0.904, P=0.02)$. 
Table 1

Univariate and multivariate analysis to identify predictors of disease-free survival of HCC patients with clear cell carcinoma

\begin{tabular}{|c|c|c|c|c|c|c|}
\hline \multirow[t]{2}{*}{ Variable } & \multicolumn{3}{|c|}{ Univariate } & \multicolumn{3}{|c|}{ Multivariate } \\
\hline & HR & $95 \% \mathrm{Cl}$ & $\begin{array}{l}P \\
\text { value }\end{array}$ & HR & $95 \% \mathrm{Cl}$ & $\begin{array}{l}P \\
\text { value }\end{array}$ \\
\hline $\begin{array}{l}\text { Age } \\
(\leq 52 / \otimes 52 \text { year })\end{array}$ & 0.757 & $\begin{array}{l}0.546- \\
1.050\end{array}$ & 0.092 & & & \\
\hline Sex (male/female) & 1.206 & $\begin{array}{l}0.716- \\
2.031\end{array}$ & 0.479 & & & \\
\hline $\begin{array}{l}\text { AFP } \\
(\leq 20 / \otimes 20 \mathrm{ng} / \mathrm{mL})\end{array}$ & 1.809 & $1.273-2.57$ & 0.001 & 1.512 & $\begin{array}{l}1.057- \\
2.161\end{array}$ & 0.023 \\
\hline $\begin{array}{l}\text { Cirrhosis } \\
\text { (presence/absence) }\end{array}$ & 2.459 & $\begin{array}{l}1.393- \\
4.342\end{array}$ & 0.001 & 2.023 & $\begin{array}{l}1.127- \\
3.631\end{array}$ & 0.018 \\
\hline $\begin{array}{l}\text { HBsAg } \\
\text { (presence/absence) }\end{array}$ & 0.767 & $\begin{array}{l}0.482- \\
1.220\end{array}$ & 0.258 & & & \\
\hline Child-Pugh class (A/B) & 0.943 & $\begin{array}{l}0.480- \\
1.854\end{array}$ & 0.865 & & & \\
\hline $\begin{array}{l}\text { Tumor number } \\
\text { (single /multiple) }\end{array}$ & 1.485 & $\begin{array}{l}1.002- \\
2.202\end{array}$ & 0.046 & - & - & 0.186 \\
\hline 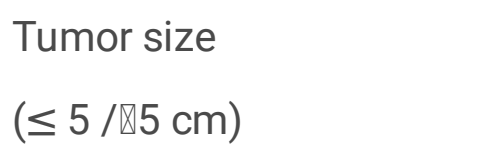 & 2.094 & $\begin{array}{l}1.448- \\
3.027\end{array}$ & $\nabla 0.001$ & 2.01 & $\begin{array}{l}1.388- \\
2.912\end{array}$ & $\otimes 0.001$ \\
\hline $\begin{array}{l}\text { Satellite nodules } \\
\text { (presence/absence) }\end{array}$ & 0.36 & $\begin{array}{l}0.232- \\
0.561\end{array}$ & 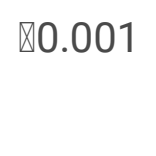 & 0.544 & $\begin{array}{l}0.343- \\
0.863\end{array}$ & 0.01 \\
\hline MVI (presence/absence) & 0.681 & $0.49-0.948$ & 0.021 & - & - & 0.900 \\
\hline $\begin{array}{l}\text { Capsule formation } \\
\text { (presence /absence) }\end{array}$ & 1.383 & $\begin{array}{l}0.997- \\
1.918\end{array}$ & 0.049 & - & - & 0.116 \\
\hline $\begin{array}{l}\text { PVTT } \\
\text { (presence /absence) }\end{array}$ & 0.497 & $\begin{array}{l}0.295- \\
0.839\end{array}$ & 0.001 & 0.531 & $\begin{array}{l}0.312- \\
0.904\end{array}$ & 0.02 \\
\hline Transfusion (yes /no) & 0.789 & $\begin{array}{l}0.540- \\
1.152\end{array}$ & 0.215 & & & \\
\hline
\end{tabular}




\begin{tabular}{|c|c|c|c|c|c|c|}
\hline \multirow[t]{2}{*}{ Variable } & \multicolumn{3}{|c|}{ Univariate } & \multicolumn{3}{|c|}{ Multivariate } \\
\hline & HR & $95 \% \mathrm{Cl}$ & $\begin{array}{l}P \\
\text { value }\end{array}$ & HR & $95 \% \mathrm{Cl}$ & $\begin{array}{l}P \\
\text { value }\end{array}$ \\
\hline $\mathrm{BCLC}(\mathrm{A} / \mathrm{B} / \mathrm{C})$ & 1.574 & $\begin{array}{l}1.258- \\
1.971\end{array}$ & $\varangle 0.001$ & - & - & 0.205 \\
\hline 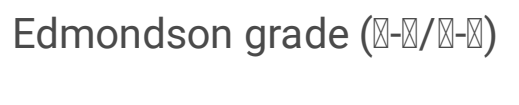 & 1.149 & $\begin{array}{l}0.793- \\
1.665\end{array}$ & 0.458 & & & \\
\hline $\mathrm{Ki}-67(\leq 30 \% / \varangle 30 \%)$ & 0.703 & $\begin{array}{l}0.503- \\
0.982\end{array}$ & 0.036 & & & \\
\hline \multicolumn{7}{|c|}{$\begin{array}{l}\text { Abbreviations: HR, hazard ratio; AFP; alpha-fetoprotein level; BCLC, Barcelona Clinic Liver Cancer; MVI, } \\
\text { microvascular invasion; PVTT, portal vein tumor thrombosis; HBsAg, serum hepatitis B surface } \\
\text { antigen. }\end{array}$} \\
\hline
\end{tabular}

\section{Predictors of OS in HCC patients with clear cell carcinoma}

Univariate analysis identified AFP level, Ki-67 (Supplementary Fig. 2), tumor size (Supplementary Fig. 2), satellite nodules (Supplementary Fig. 2), MVI, capsule formation (Supplementary Fig. 2), PVTT, blood transfusion, BCLC stage and liver cirrhosis as significantly associated with OS of patients with clear cell carcinoma. Multivariate analysis identified the following as independent predictors of OS (Table 2): Ki-67 (HR 1.94, 95\% Cl 1.227-3.068, $P=0.005$ ), tumor size (HR 3.638, 95\% Cl 1.989-6.654, $P<0.001$ ), satellite nodules (HR 0.402, 95\% Cl 0.230-0.701, $P=0.001)$ and capsule formation (HR 2.062, 95\% Cl 1.278-3.329, $P=0.003)$. 
Table 2

Univariate analysis and multivariate analysis of risk factors related to OS of HCC patients with clear cell carcinoma

\begin{tabular}{|c|c|c|c|c|c|c|}
\hline \multirow[t]{2}{*}{ Variables } & \multicolumn{3}{|c|}{ Univariate } & \multicolumn{3}{|c|}{ Multivariate } \\
\hline & $\mathrm{HR}$ & $95 \% \mathrm{Cl}$ & $\begin{array}{l}\mathrm{P}- \\
\text { value }\end{array}$ & $\mathrm{HR}$ & $95 \% \mathrm{Cl}$ & $\begin{array}{l}\mathrm{P}- \\
\text { value }\end{array}$ \\
\hline Age $(\leq 52 / \bowtie 52$ year $)$ & 0.803 & $\begin{array}{l}0.518- \\
1.245\end{array}$ & 0.352 & & & \\
\hline Sex (male/female) & 1.022 & $\begin{array}{l}0.526- \\
1.986\end{array}$ & 0.949 & & & \\
\hline $\operatorname{AFP}(\leq 20 / 囚 20 \mathrm{ng} / \mathrm{mL})$ & 2.03 & $\begin{array}{l}1.242- \\
3.317\end{array}$ & 0.002 & - & - & 0.134 \\
\hline $\begin{array}{l}\text { Cirrhosis } \\
\text { (presence/absence) }\end{array}$ & 2.436 & $\begin{array}{l}1.156- \\
5.136\end{array}$ & 0.016 & - & - & 0.094 \\
\hline $\begin{array}{l}\text { HBsAg } \\
\text { (presence/absence) }\end{array}$ & 0.639 & $\begin{array}{l}0.327- \\
1.248\end{array}$ & 0.185 & & & \\
\hline Child-Pugh class (A/B) & 0.962 & $\begin{array}{l}0.351- \\
2.639\end{array}$ & 0.940 & & & \\
\hline $\begin{array}{l}\text { Tumor number } \\
\text { (single /multiple) }\end{array}$ & 1.31 & $\begin{array}{l}0.783- \\
2.192\end{array}$ & 0.302 & & & \\
\hline $\begin{array}{l}\text { Tumor size } \\
(\leq 5 / \otimes 5 \mathrm{~cm})\end{array}$ & 3.904 & $\begin{array}{l}2.106- \\
7.236\end{array}$ & $\varangle 0.001$ & 3.638 & $\begin{array}{l}1.989- \\
6.654\end{array}$ & $\nabla 0.001$ \\
\hline $\begin{array}{l}\text { Satellite nodules } \\
\text { (presence/absence) }\end{array}$ & 0.248 & $\begin{array}{l}0.145- \\
0.421\end{array}$ & $\varangle 0.001$ & 0.402 & $\begin{array}{l}0.230- \\
0.701\end{array}$ & 0.001 \\
\hline $\begin{array}{l}\text { MVI } \\
\text { (presence/absence) }\end{array}$ & 0.521 & $\begin{array}{l}0.334- \\
0.811\end{array}$ & 0.003 & - & - & 0.171 \\
\hline $\begin{array}{l}\text { Capsule formation } \\
\text { (presence /absence) }\end{array}$ & 2.149 & $\begin{array}{l}1.367- \\
3.377\end{array}$ & 0.001 & 2.062 & $\begin{array}{l}1.278- \\
3.329\end{array}$ & 0.003 \\
\hline $\begin{array}{l}\text { PVTT (presence } \\
\text { /absence) }\end{array}$ & 0.394 & $\begin{array}{l}0.202- \\
0.768\end{array}$ & 0.002 & - & - & 0.310 \\
\hline Transfusion (yes /no) & 0.519 & $\begin{array}{l}0.323- \\
0.835\end{array}$ & 0.006 & - & - & 0.122 \\
\hline $\mathrm{BCLC}(\mathrm{A} / \mathrm{B} / \mathrm{C})$ & 1.745 & $\begin{array}{l}1.303- \\
2.336\end{array}$ & $\varangle 0.001$ & - & - & 0.353 \\
\hline
\end{tabular}

Abbreviations: HR, hazard ratio; AFP, alpha-fetoprotein level; BCLC, Barcelona Clinic Liver Cancer; MVI, microvascular invasion; PVTT, portal vein tumor thrombosis; HBsAg, serum hepatitis B surface antigen. 


\begin{tabular}{|c|c|c|c|c|c|c|}
\hline \multirow{2}{*}{ 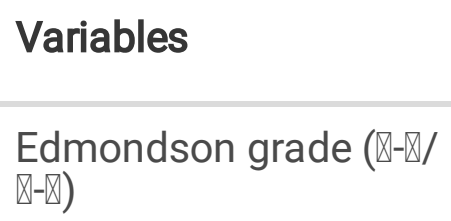 } & \multicolumn{3}{|l|}{ Univariate } & \multicolumn{3}{|c|}{ Multivariate } \\
\hline & 1.204 & $\begin{array}{l}0.723- \\
2.003\end{array}$ & 0.474 & & & \\
\hline Ki-67 ( $\leq 30 / \varangle 30 \%)$ & 0.469 & $\begin{array}{l}0.302- \\
0.727\end{array}$ & 0.001 & 1.94 & $\begin{array}{l}1.227- \\
3.068\end{array}$ & 0.005 \\
\hline \multicolumn{7}{|c|}{$\begin{array}{l}\text { Abbreviations: HR, hazard ratio; AFP, alpha-fetoprotein level; BCLC, Barcelona Clinic Liver Cancer; MVI, } \\
\text { microvascular invasion; PVTT, portal vein tumor thrombosis; HBSAg, serum hepatitis B surface } \\
\text { antigen. }\end{array}$} \\
\hline
\end{tabular}

\section{Prognostic nomogram for HCC patients with clear cell carcinoma}

To predict DFS and OS of HCC patients with clear cell carcinoma after hepatectomy, two nomograms were formulated by incorporating all the independent predictors of each respective outcome that emerged from multivariate analysis. Cirrhosis and tumor size exerted the strongest influence on DFS of patients with clear cell carcinoma, followed by satellite nodules, AFP and PVTT (Fig. 3). In contrast, tumor size and satellite nodules exerted the strongest influence on OS, followed by capsule formation and Ki-67 (Fig. 4). The C-indexes were 0.660 for DFS prediction and 0.730 for OS prediction. Both nomograms predicted 1-, 3- and 5-year survival rates in good agreement with the observed rates (Supplementary Fig. 3-4).

\section{Discussion}

As diagnostic techniques have improved, an increasing number of HCC patients have been found to have clear cell carcinoma that nevertheless fails to reach the abundance traditionally used to diagnose PCCCL. Therefore it is important to clarify the implications of the minority presence of clear cell carcinoma on the prognosis of HCC patients, especially after hepatectomy. Our results support the idea that the presence of clear cell carcinoma improves the post-resection prognosis. In addition, our analyses allowed us to construct nomograms to predict OS and DFS of HCC patients with clear cell carcinoma.

The appearance of "clear cells" has been attributed to metabolic derangement within the tumor nodule or inadequate vascular development that leads to insufficient blood supply [16]. This may explain why PCCCL is less malignant than other HCC subtypes. Previous studies have associated higher AFP [17] and Ki-67 levels [18], larger tumors [19], perioperative blood transfusion [20], and presence of portal vein tumor thrombosis (PVTT) [21], satellite nodules, [22] and microvascular invasion (MVI) [23] as predictors of poor prognosis after surgery to treat HCC. In our study, clear cell carcinoma in HCC was associated with significantly lower AFP and Ki-67 levels, significantly smaller tumors and significantly lower incidences of PVTT, satellite nodules, MVI and perioperative blood transfusion. This may help explain why PCCCL is less malignant than other HCC subtypes. In addition, the higher rate of pseudo-capsule formation in patients with PCCCL $[6,24]$ may limit tumor growth and spread as well as facilitate tumor resection and treatment. 
Our multivariate analysis identified liver cirrhosis, tumor size, satellite nodules, Ki-67 and AFP level as independent predictors of DFS in HCC patients with clear cell carcinoma. It identified Ki-67, tumor size, satellite nodules and capsule formation as independent predictors of OS. Cirrhosis is a significant risk factor for recurrence after resection for several HCC subtypes $[25,26]$, as well as primary clear cell carcinoma [27], Cirrhosis has also been shown to predict OS [6,9] and DFS [9] in primary clear cell carcinoma. Similarly, previous work has found tumor size to independently predict OS and DFS in primary clear cell carcinoma $[9,10,12]$, Our results with AFP level are supported by previous reports on PCCCL [9], and so are our results with capsule formation $[3,13]$.

Our results should be interpreted with caution because our patients came from a single center, and our analysis was retrospective. We lacked data on certain factors that can also influence survival after hepatectomy, including programmed death ligand 1 (PD-L1) [28], plasma fibrinogen [29] and surgical margin [30]. Our findings should be verified and extended in prospective trials.

\section{Conclusion}

The presence of clear cell carcinoma in HCC is associated with better prognosis after hepatectomy. Tumor size and satellite nodules may be independent predictors of both DFS and OS of HCC patients with clear cell carcinoma. Capsule formation and Ki-67 may also be independent predictors of OS, while AFP and PVTT may be independent predictors of DFS. We were able to develop intuitive nomograms to predict survival and recurrence in HCC patients with clear cell carcinoma, which may help improve their management.

\section{Declarations}

\section{Data Availability}

The data that support the finding of this study is available from the corresponding author upon reasonable request.

\section{Consent for publication}

Not applicable.

\section{Authors' contributions}

YH Deng, SL Zhu, and LN Qi mainly participated in material preparation, data collection and analysis. The first draft of the manuscript was written by YH Deng. ZS Chen and L Ma was mainly participated in study conception and design, fund collected, supervision and critical revision. All authors read and approved the final manuscript.

\section{Funding}


This study was supported by Youth Science Foundation of Guangxi Medical University (No: GXMUYSF201923).

\section{Conflict of interest}

No potential conflicts of interest were disclosed.

\section{Ethical approval}

This study was approved by the Institutional Ethics Committee of Guangxi Medical University Cancer Hospital.

\section{Informed consent}

Informed consent was obtained from the patients for their data to be used for research purposes.

\section{References}

[1] Ferlay J, Soerjomataram I, Dikshit R, et al. Cancer incidence and mortality worldwide: sources, methods and major patterns in GLOBOCAN 2012. Int J Cancer. 2015; 136(5): E359-386.

[2] Liu J, Tsai H, Hsu S, et al. Clear cell and non-clear cell hepatocellular carcinoma: a case report and literature review. Kaohsiung J Med Sci. 2004; 20:78-81.

[3] Ji S, Li Q, Dong H. Therapy and prognostic features of primary clear cell carcinoma of the liver. World J Gastroenterol. 2010; 16:764.

[4] Emile JF, Lemoine A, Azoulay D, et al. Histological, genomic and clinical heterogeneity of clear cell hepatocellular carcinoma. Histopathology. 2001; 38: 225-231.

[5] Adamek HE, Spiethoff A, Kaumann V, et al. Primary clear cell carcinoma of noncirrhotic liver: immunohistochemical discrimination of hepatocellular and cholangiocellular origin. Dig Dis Sci. 1998; 43: 33-38.

[6] Liu Z, Ma W, Li H, et al. Clinicopathological and prognostic features of primary clear cell carcinoma of the liver. Hepatol Res. 2008; 38:291-299.

[7] Edmondson HA. Tumours of the liver and intrahepatic bile ducts. In: Atlas of tumor pathology. Washington DC: Armed Forces Institute of Pathology. 1958;49.

[8] Lai CL, Wu PC, Lam KC, et al. Histologic prognostic indicators in hepatocellular carcinoma. Cancer. 1979; 44:1677-1683.

[9] Li T, Fan J, Qin L X, et al. Risk factors, prognosis, and management of early and late intrahepatic recurrence after resection of primary clear cell carcinoma of the liver. Ann Surg Oncol. 2011; 18(7): 1955- 
1963.

[10] Chen Z S, Zhu S L, Qi L N, et al. Long-term survival and prognosis for primary clear cell carcinoma of the liver after hepatectomy. Onco Targets Ther. 2016; 9: 4129-4135.

[11] McDermott WV, Cady B, Georgi B, et al. Primary cancer of the liver. Evaluation, treatment, and prognosis. Arch Surg. 1989; 124:552-554.

[12] Zhang Z, Xie H, Chen P, et al. Development and Identification of a Nomogram Prognostic Model for Patients with Primary Clear Cell Carcinoma of the Liver. Medical Science Monitor. 2020; 26.

[13] Liu Z, Ma W, Li H, et al. Clinicopathological and prognostic features of primary clear cell carcinoma of the liver. Hepatol Res. 2008; 38:291-299.

[14] Zhu SL, Zhong JH, Ke Y, et al. Efficacy of hepatic resection vs transarterial chemoembolization for solitary huge hepatocellular carcinoma. World J Gastroenterol. 2015; 21:9630-9637.

[15] Belghiti J, Noun R, Malafosse R, et al. Continuous versus intermittent portal triad clamping for liver resection: a controlled study. Ann Surg. 1999; 229:369.

[16] Yang SH, Watanabe J, Nakashima O, et al. Clinicopathologic study on clear cell hepatocellular carcinoma. Pathol Int. 1996; 46: 503-509.

[17] Xia Y, Yan ZL, Xi T, et al. A case-control study of correlation between preoperative serum AFP and recurrence of hepatocellular carcinoma after curative hepatectomy. Hepatogastroenterology. 2012; 59(119): 2248-2254.

[18] Luo Y, Ren F, Liu Y, et al. Clinicopathological and prognostic significance of high Ki-67 labeling index in hepatocellular carcinoma patients: a meta-analysis. Int J Clin Exp Med. 2015;8(7):10235-10247.

[19] Park SK, Jung YK, Chung DH, et al. Factors influencing hepatocellular carcinoma prognosis after hepatectomy: a single-center experience. Korean J Intern Med. 2013;28(4):428-438.

[20] Wada $\mathrm{H}$, Eguchi $\mathrm{H}$, Nagano $\mathrm{H}$, et al. Perioperative allogenic blood transfusion is a poor prognostic factor after hepatocellular carcinoma surgery: a multi-center analysis. Surg Today. 2018;48(1):73-79.

[21] Zhou L, Rui JA, Wang SB, et al. Outcomes and prognostic factors of cirrhotic patients with hepatocellular carcinoma after radical major hepatectomy. World J Surg. 2007;31(9):1782-1787.

[22] Shi C, Zhao Q, Liao B, et al. Anatomic resection and wide resection margin play an important role in hepatectomy for hepatocellular carcinoma with peritumoural micrometastasis. ANZ J Surg. 2019;89(11): E482-E486.

[23] Zhang X, Li J, Shen F, Lau WY. Significance of presence of microvascular invasion in specimens obtained after surgical treatment of hepatocellular carcinoma. J Gastroenterol Hepatol. 2018;33(2):347- 
[24] Liu QY, Li HG, Gao M, et al. Primary clear cell carcinoma in the liver: CT and MRI findings. World Journal Gastroenterol. 2011;17(7): 946-952.

[25] Nagao T, Inoue S, Yoshimi F, et al. Postoperative recurrence of hepatocellular carcinoma. Ann Surg. 1990; 211:28-33.

[26] Fuster J, Garcia-Valdecasas JC, Grande L, et al. Hepatocellular carcinoma and cirrhosis. Results of surgical treatment in a European series. Ann Surg. 1996; 223:297-302.

[27] Poon RT, Fan ST, Ng IO, et al. Wong J. Different risk factors and prognosis for early and late intrahepatic recurrence after resection of hepatocellular carcinoma. Cancer. 2000; 3: 500-507.

[28] Dai X, Xue J, Hu J, et al. Positive Expression of Programmed Death Ligand 1 in Peritumoral Liver Tissue is Associated with Poor Survival after Curative Resection of Hepatocellular Carcinoma. Transl Oncol. 2017;10(4):511-517.

[29] Dai T, Peng L, Lin G, et al. Preoperative elevated plasma fibrinogen level predicts tumor recurrence and poor prognosis in patients with hepatocellular carcinoma. J Gastrointest Oncol. 2019;10(6):10491063.

[30] Zhong FP, Zhang YJ, Liu Y, Zou SB. Prognostic impact of surgical margin in patients with hepatocellular carcinoma: A meta-analysis. Medicine (Baltimore). 2017;96(37): e8043.

\section{Figures}
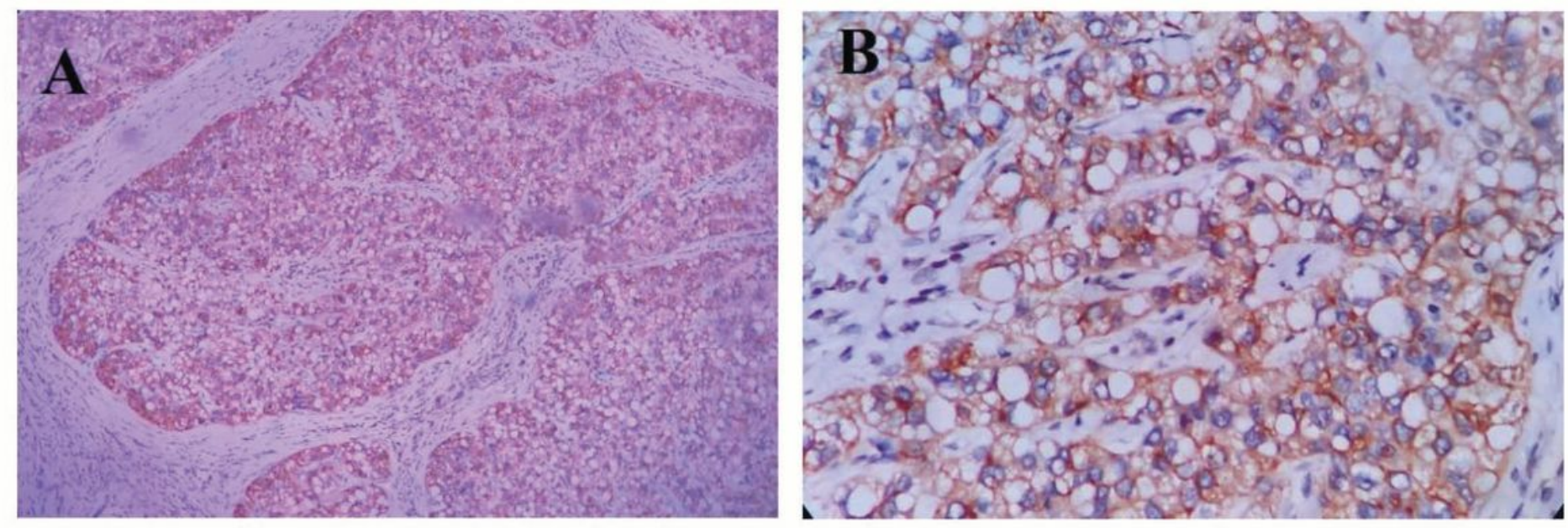

Figure 1 
Tumor section from a patient with hepatocellular carcinoma containing clear cell carcinoma, after staining with hematoxylin and eosin. (A) Magnification, $\times 40$. (B) Magnification, $\times 100$.
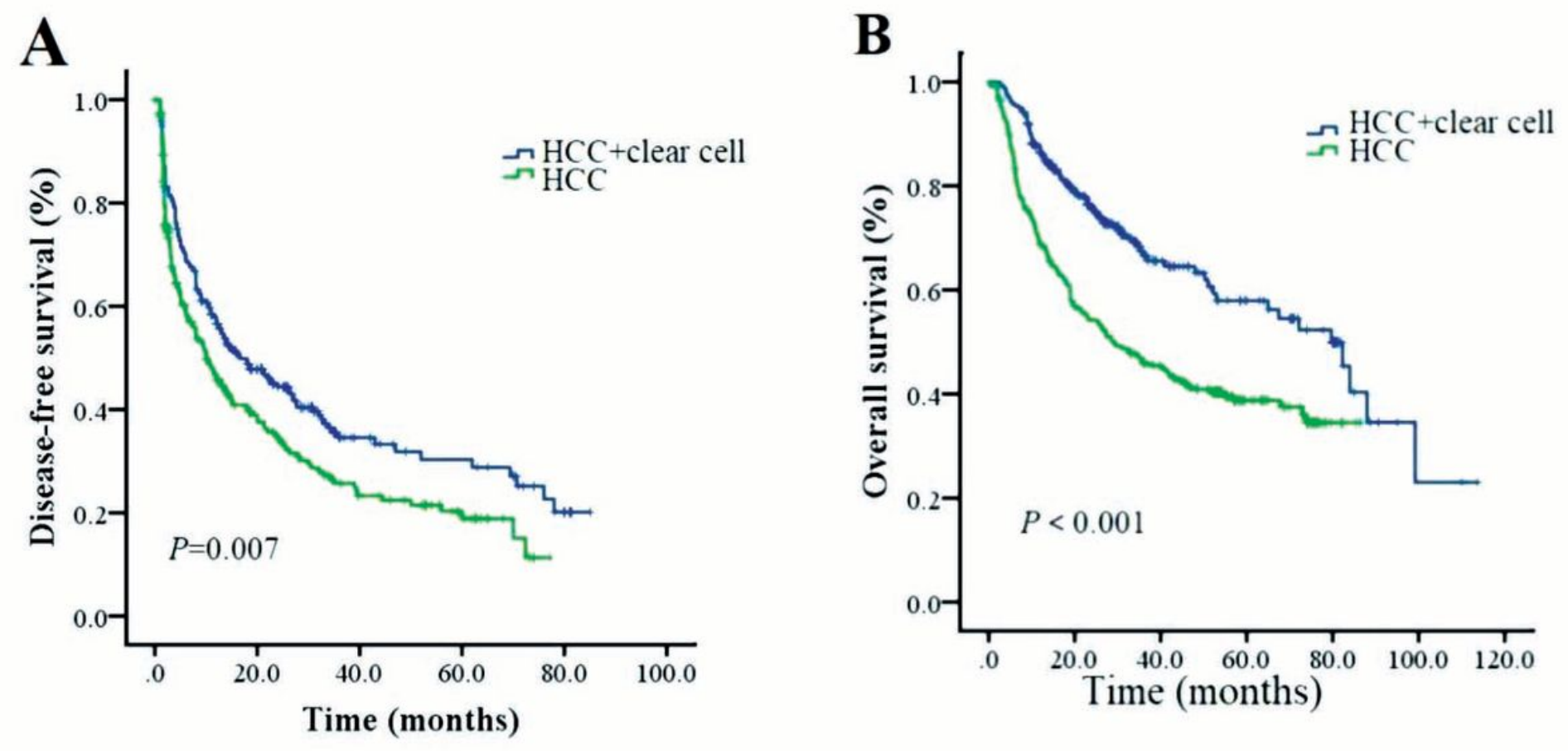

Figure 2

Comparison of survival between HCC patients with or without clear cell carcinoma (A) Disease-free survival of HCC patients with or without clear cell carcinoma. (B) Overall survival of HCC patients with or without clear cell carcinoma. 


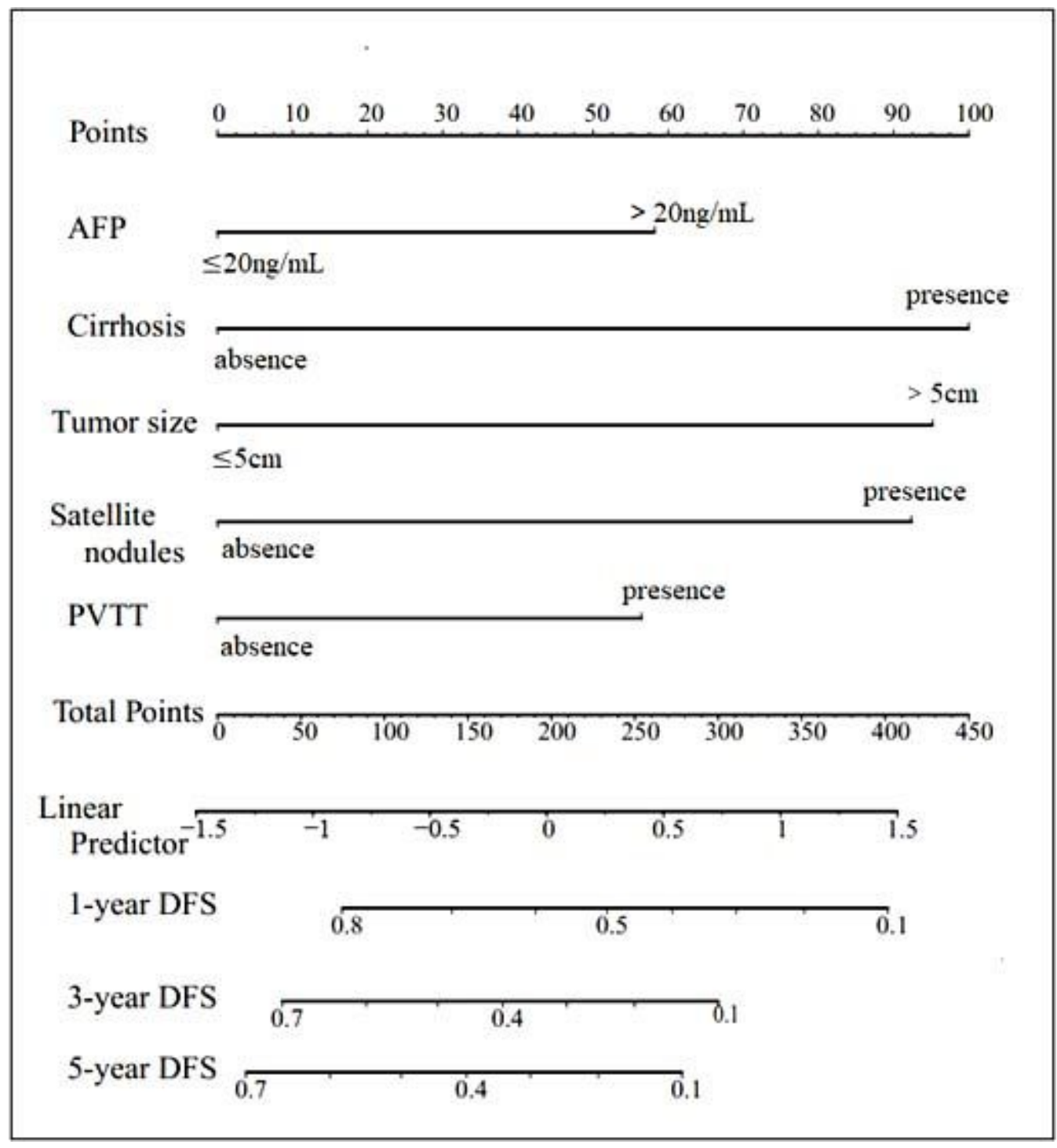

\section{Figure 3}

Nomogram for predicting 1-year, 3-year, and 5-year disease-free survival (DFS) of HCC patients with clear cell carcinoma. 
Points $\quad \begin{array}{lllllllllll}0 & 10 & 20 & 30 & 40 & 50 & 60 & 70 & 80 & 90 & 90\end{array}$

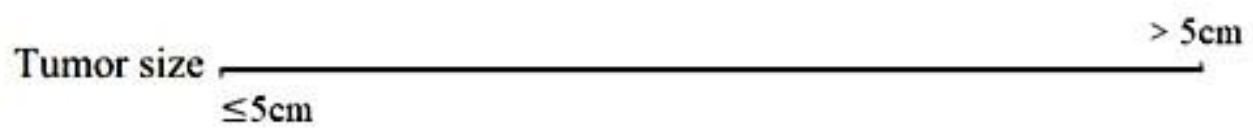

Satellite
nodules absence

absence

Capsule

formation presence

Ki-67 $\leq 30 \%$

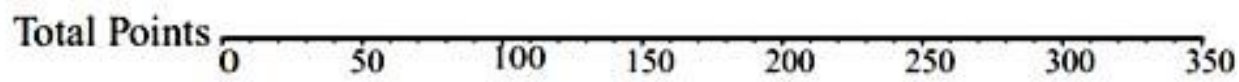

Linear

$\begin{array}{llllllllll}\text { Predictor } & -1.5 & -1 & -0.5 & 0 & 0.5 & 1 & 1.5 & 2 & 2.5\end{array}$

1-year OS

$0.95+0.8+7+3$

3-year OS

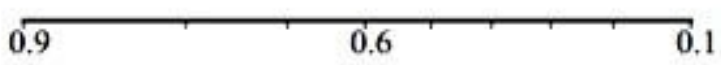

5-year $\mathrm{OS}_{0.9}$

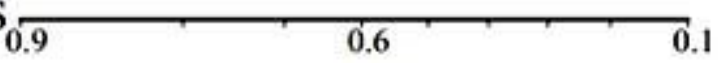

\section{Figure 4}

Nomogram for predicting 1-year, 3-year, and 5-year overall survival (OS) of HCC patients with clear cell carcinoma.

\section{Supplementary Files}

This is a list of supplementary files associated with this preprint. Click to download.

- SupplementaryData.docx 